\title{
Sickle cell disease in Oman and HBS Oman: a brief review
}

Keywords: chronic anaemia, haemoglobinopathie, acute ischaemic, haemolytic, splenomegaly, heterozygosity, heterozygous

Abbreviations: SCD, sickle cell disease; HU, hydroxyurea; FDA, food and drug administration; G6PD, glucose-6-phosphate dehydrogenase; BMT, bone marrow transplantation

\section{Introduction}

The first medical case of SCD was described by James Herrick in 1910. It is one of the most common hereditary haemoglobinopathies with most cases from African and or Arab-Indian origin. SCD complications can be divided into two major groups, chronic anaemia and acute ischaemic incidents. ${ }^{1}$ Chronic hemolytic anemia of varying severity is a day-to-day struggle. Additionally, patients suffer from sporadic pain-crisis incidents arising from thrombus formation in the vascular system. The most life threatening of these is acute chest syndrome, ${ }^{2}$ cerebral vasculopathy ${ }^{3}$ and renal failure. ${ }^{4}$ These and other complications contribute to a high mortality of SCD patients, especially before seven years of age in areas with poor healthcare. SCD is also associated with a poor quality of life and severe organ damage. $^{5}$ Moreover, treatment of SCD is still only supportive, employing periodic blood exchange transfusions and hydroxyurea (HU), which is the only US Food and Drug Administration (FDA) approved SCD therapy. ${ }^{6}$

Historically, Oman was the principal trading port of the Arabian Gulf region. Its high trade activities resulted in mixed social and ethnic background of the Omani people. Zanzibar, Pakistan and part of Iran were classified as malaria endemic areas as well as some part of the Arabian Peninsula (Malaria Belt). Malaria is one of the main reasons of the occurrence of sickle cell disease (SCD), thalassaemia, glucose-6-phosphate dehydrogenase (G6PD) deficiency and other erythrocyte defects which are the most common Mendelian diseases of mankind. Different populations have evolved different genetic variants to protect against malaria. ${ }^{7}$ The recent statistics shows that there are around 400 patients with thalassaemia major and 3000 with sickle cell disorders in Oman. ${ }^{8}$ The birth prevalence of infants with haemoglobin disorders was 3.5-4.7/1,000. ${ }^{9}$ Around $6 \%$ of Omanis are carriers of the gene for sickle cell anaemia, $2-3 \%$ for $\beta$-thalassaemia and $45 \%$ are carriers of the $\alpha$-thalassaemia gene. ${ }^{10-13}$ The other red cell abnormality common in Oman is G6PD deficiency which is found in $28 \%$ of males and $12 \%$ of females. ${ }^{10,14}$

Although Oman started diagnosing SCD in early 1980's; however, there is no published data on the first case. In Oman, almost $40 \%$ of the patients were diagnosed before the age of one year. The severity index correlated well with the age of diagnosis. More than two thirds of SCD cases were running a mild course of the disease. The majority of the patients $(61.2 \%)$ were homozygous sickle cell anemia followed by double heterozygous types mainly sickle cell $\beta$-thalassemia. African Haplotypes were predominant $(68.53 \%)$ and $80 \%$ of those screened for $\alpha$-globin gene mutations were heterozygous or homozygous for $\alpha$-Thalassemia. There was no significant correlation between

\author{
Volume 4 Issue $6-2017$
}

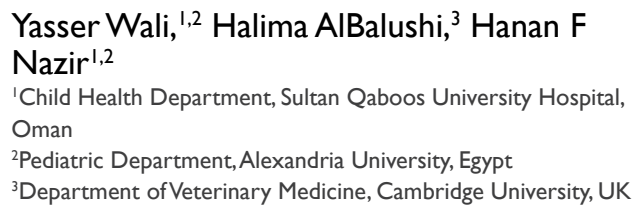

Correspondence: Yasser Wali, Child Health Department, Sultan Qaboos University Hospital, Muscat, Oman, Email yasser_wali@hotmail.com

Received: August 14, 2016 | Published: June 07, 2017

phenotype and haplotype forms and the severity of the disease. About half of the patients had splenomegaly and preserved splenic function which may relate to the low incidence of infections observed in our patients compared to other reports. There was low documentation of acute chest syndrome and cerebrovascular accidents compared to published data. Other complications are comparable to other studies. Factors possibly influencing the severity of the disease are the presence of alpha thalassemia gene mutation and high $\mathrm{Hb} F$ levels. ${ }^{15,16}$

In 1989 Lang down and co-workers from Cambridge reported the first case of HbS-Oman. HbS/S-Oman is a severe variant of sickle haemoglobinopathy that results from 2 simultaneous mutations in the same B globin chain. The first is the classic Bs mutation (B6 Glu $\rightarrow$ val) and the second is in position 121 (B121 Glu $\rightarrow$ lys). ${ }^{17,18}$ Previous reports explained that carriers of this disease in Oman present in 2 different clinical syndromes:

i. High expressors of $\mathrm{HbS} / \mathrm{S}-O m a n$ and concominant- $\alpha / \alpha \alpha$ thalassemia (expressing about $20 \% \mathrm{HbS} / \mathrm{S}$-Oman) presenting in the heterozygote state with clinical manifestations of Sickle Cell Disease of varying severity.

ii. Low expressors of HbS-Oman with concominant- $\alpha /-\alpha$ thalassemia (expressing about 14\% of HbS-Oman) and they are asymptomatic with no clinical syndrome. ${ }^{19}$

In the literature only 6 carriers have been described so far. ${ }^{17-19}$ Recently, we observed quite a number of carriers in our OPD presenting as severe forms. Also, we have identified for the first time in Oman compound heterozygotes HbS-Oman that resulted in a very severe clinical manifestations presenting as transfusion dependent thalassemia major with hypersplenism early in life that was not controlled, solely, by hypertransfusion and needed both splenectomy at the age of one year and bone marrow transplantation in the second year of life. Recently we studied 4 affected families through pedigree evaluation and screened all family members by $\mathrm{Hb}$ variant analyses and HPLC. We identified 62patients with $\mathrm{Hb}$ S Oman heterozygosity of which 6patients had compound heterozygosity for HB S-S Oman. 


\section{Conclusion}

Of the 6patients with compound heterozygosity for HB S-S Oman, 2patients underwent Bone marrow Transplantation (BMT). The first patient underwent BMT at the age of 5years. This patient had an extremely severe course of the disease with recurrent splenic sequestration despite receiving regular blood transfusions since 6 months of age. The other patient underwent BMT recently at age of 16years due to severe course of the disease with $\mathrm{h} / \mathrm{o}$ stroke and regular blood transfusion. We evaluated the 56patients with $\mathrm{HbS}$ Oman heterozygosity, their clinical features range from being asymptomatic to severe course of the disease. We compared the Red Cell Indices of patients with Heterozygous HbS Oman and compound heterozygous HbS-S Oman and detected lower mean $\mathrm{Hb}, \mathrm{MCV}, \mathrm{MCH}$ and higher RDW values in compound heterozygous patients compared to SCD patients. We are currently investigating the genetic modifiers and the red cell biology of these patients.

\section{Acknowledgements}

None.

\section{Conflict of interest}

The author declares no conflict of interest.

\section{References}

1. Stuart MJ, Nagel RL. Sickle-cell disease. Lancet. 2004;364(9442):13431360 .

2. Vichinsky EP, Neumayr LD, Earles AN, et al. Causes and outcomes of the acute chest syndrome in sickle cell disease. National acute chest syndrome study group. $N$ Engl J Med. 2000;342(25):1855-1865.

3. Frempong KO, Weiner SJ, Sleeper LA, et al. Cerebrovascular accidents in sickle cell disease: rates and risk factors. Blood. 1998;91(1):288-294.

4. Scheinman JI. Ssickle cell disease and the kidney. Nat Clin Pract Nephrol. 2009;5(2):78-88.

5. Rees DC, Williams TN, Gladwin MT. Sickle-cell disease. Lancet. 2010;376(9557):2018-2031.

6. Neville KA, Panepinto JA. Pharmacotherapy of sickle cell disease. $18^{\text {th }}$ Expert Committee on the Selection and Use of Essential Medicines, USA; 2011. p. 1-16.
7. Kwiatkowski DP. How malaria has affected the human genome and what human genetics can teach us about malaria. Am J Hum Genet. 2005;77(2):171-192.

8. Rajab A, Al Rashdi I, Al Salmi Q. Genetic services and testing in the Sultanate of Oman. Sultanate of Oman steps into modern genetics. $J$ Community Genet. 2013;4(3):391-397.

9. RajabA, Patton MA. Development and use of a national hemoglobinopathy register in Oman. Community Genetics. 1999;2:47-48

10. Alkindi S, Al-Zadjali S, Al-Madhani A, et al. Forecasting hemoglobinopathy burden through neonatal screening in Omani neonates. Hemoglobin. 2010;34(2):135-144.

11. White JM, Christie BS, Nam D, et al. Frequency and clinical significance of erythrocyte genetic abnormalities in Omanis. J Med Genet. 1993;30(5):396-400.

12. Daar S, Hussein HM, Merghoub T, et al. Spectrum of B thalassemia mutations in Oman. Ann N Y Sci. 1998;850:404-406.

13. Daar S, Hussein HM, Gravell D, et al. Genetic epidemiology of $\mathrm{Hb}$ $\mathrm{S}$ in Oman: Multicentric origen for the beta $\mathrm{S}$ gene. Am J Hematol. 2000;64(1):39-46.

14. Daar S, Vulliamy TJ, Kaeda J, et al. Molecular characterization of G6PD deficiency in Oman. Hum Hered. 1996;46(3):172-176.

15. Al-Lamki Z, Wali YA, Wasifuddin MS, et al. Natural History of Sickle hemoglobinopathy in Omani Children. International Journal of Paediatric Haematology and Oncology. 2000;7(2):101-107.

16. Wali YA, Al-Lamki Z, Hussein SS, et al. Splenic function in omani children with sickle cell disease: correlation with severity index, hemoglobin phenotype, iron status, and $\alpha$-thalassemia trait. Pediatr Hematol Oncol. 2002;19(7):491-500.

17. Nagel RL, Daar S, Romero JR, et al. HbS-oman heterozygote: a new dominant sickle syndrome. Blood. 1998;92(11):4375-4382.

18. Langdown JV, Williamson D, Knight CB, et al. A new doubly substituted sickling haemoglobin: HbS-Oman. Br J Haematol. 1989;71(3):443-444.

19. Venugopal S, Shaju A, Dhuri S, et al. Compound heterozygosity for $\mathrm{Hb} \mathrm{S}$ and Hb S-Oman: case report. Sultan Qaboos Univ Med J. 2008;8(3):344 346. 